\title{
WHAT DRIVES YOUNG WOMEN TO JOIN THE PAKISTAN ARMED FORCES? AN EXPLORATORY STUDY OF MOTIVATIONAL FACTORS
}

\author{
Nazia Mustafa, Shoaib Kiani \\ General Head Quarter, Rawalpindi Pakistan
}

\begin{abstract}
Objective: to explore the motivational factors for women to join Pakistan army. Study Design: Exploratory study design.

Place and Duration: The study was conducted at Army selection and Recruitment Centre on the female graduates from various universities of Islamabad/Rawalpindi who were coming for induction in army, from March 2018.

Methodology: The study was conducted in two phases; in phase I, Semi-structured interviews of 10 lady officers were carried out to gauge the motivational factors to join Army. In phase II, data of 792 female graduates from various universities of Islamabad/Rawalpindi was collected through socio-demographic form and the checklist about motivational factors developed during phase I to join armed forces.

Results: Results revealed that maximum individuals (22\%) graded "Patriotism" as prime reason to join Army while a minor segment $(1 \%)$ cited financial incentive as driving factor. Percentages of other factors, in order of precedence are; "Feeling Proud" (18\%), "Strong Social Standing" (16\%), “Quality of Life” (10\%), Charm of Uniform (8\%), Bright Career (6\%), Job Security (5\%), Family Lineage (5\%), Adventurous Job (5\%) and Marriage (4\%). Further to this, there were differences in women's motivation to join Army from various professions.

Conclusion: Motivation for opting military career is a complex phenomenon of inter-related factors. Therefore, we should consider all these factors together to select highly motivated, skilled/qualified and loyal individuals.
\end{abstract}

Keywords: Female officers, Pakistan army, Psychological motivation.

This is an Open Access article distributed under the terms of the Creative Commons Attribution License ( https://creativecommons.org/licenses/by-nc/4.0/), which permits unrestricted use, distribution, and reproduction in any medium, provided the original work is properly cited.

\section{INTRODUCTION}

Pakistan Army is a globally acclaimed military organization due to its significant contributions in defence and security regimes. Despite the enormity of challenges and risks it has withstood test of times and performed as per national expectations. This organizational credibility can be directly associated to valor and strong psychological motivation of its officers \& men ${ }^{1}$.

Psychological motivation is a phenomenon which stimulates and reinforces the human behavior. It can be intrinsic (driven by within) or extrinsic (driven by outside). Literature reveals that intrinsic motivation is more influential as compared to extrinsic motivation because it operates through individual enjoyment, curiosity and pleasure ${ }^{2}$. Owing to the vitality of intrinsic motivation, military selectors try to find it out in candidates during their recruitment. As individuals with fragile motivations are unlikely to meet the arduous training standards and demanding service conditions therefore are prone to quit under rigorous environment.

Globally, multiple studies and research has been conducted to find the motivation of individuals joining

Correspondence: Dr Nazia Mustafa, Flat \# 2, Block 1, 206 Tufail Road, Rawalpindi Pakistan

Received: 10 Feb 2021; revised received: 21 Apr 2021; accepted: 04 May 2021 armed forces. Cardinal factors include, defence of the country, forming part of history, reasonable income, structured army life and following the family traditions ${ }^{3}$. Moreover, patriotism and remunerations i.e. education, healthcare, housing, and post-retirement benefits are also contributing factors leading to motivation for military profession ${ }^{4}$. Few studies conclude that institutional and occupational values, overlapping ethos of call to serve, perceptions of honor and desire for new adventures urge few people to join profession of $\mathrm{arms}^{5}$.

Available literature opines that women unlike men have different reasons to join military service. According to a 2016 survey of recruits by the DOD's Joint Advertising, Market Research \& Studies (JAMRS) Office, most women join armed forces to make positive difference in their countries as compared to males. Empirically, more females $(39 \%)$ than males $(27 \%)$ chose to become members of the armed forces to make a positive difference in their communities. Out of $73 \%$ of women cited travel as their main reason, $52 \%$ joined in order to pay for future education and $45 \%$ saw the educational opportunities within the service as a good reason for joining 6 . A qualitative study was conducted to see the motivation of Women Veterans in which semi-structured interviews of 18 enlisted female service members and veterans was carried out and result 
revealed that opportunity to serve as professional military career emerged as main theme ${ }^{1,7}$. Few other studies also conclude that women consider military as most attractive and secure job as compared to civil jobs ${ }^{8,9}$. Factually, motivational factors for military profession are indirectly shaped by education and social institutions prior to joining and are typically reinforced over time $^{10}$.

A significant knowledge gap exists on the subject in Pakistan. During intellectual discourse only one local study on a sample of 50 boys (students of matriculation and Intermediate from different army colleges of Pakistan) was found. Study concluded that the students wanted to join army to achieve the status of martyrdom and to enjoy a Quality of Life ${ }^{1}$. Although the study has joined two extremes as leading reasons for joining armed forces as career i.e. as postulate of eternal divinity is in a contrast to proclivity for worldly gains. However, no such study has been carried out on females so far. In consonance to it, present study aims to fill in research gap on this vital facet and figure out the psychological motivation of female graduates from various field of education joining armed forces.

\section{METHODOLOGY}

The main objective of this study was to find out the most common motivational factors to join Arm Forces among females and the study was conducted at Army selection and Recruitment Centre, Rawalpindi over a period of one month, March, 2018. The data was collected from 792 female graduates from various universities of Islamabad/Rawalpindi who were coming for induction in army through Non probability-convenience sampling technique. Sample size was calculated by using the WHO sample size calculator. by keeping the prevalence of psychological motivation (56\%) among students from a study conducted in Pakistan by Rauff in $2010^{1}$.

Initially, Semi-structured interviews of 10 lady officers have been carried out and a Checklist of 11 motivational factors was generated in first phase of the study (in which $1^{\text {st }}$ motivational factor was "financial reasons" and researcher kept the factor "marriage" at the last number in hierarchy).

After this, Checklist of motivational factors along with Socio-demographic form and informed consent were given to the 900 participants. Assurance was given to them that personal information given by them will be kept confidential and used for research purpose only. They were asked to rate each motivational factor to be placed in any order of the hierarchy they want.
After completion, questionnaires were collected back and data screening has been done. It was found that, out of 900 questionnaires only 792 were completed. Incomplete forms were not included in the study. The data was entered on SPSS version 24 and analyzed. Descriptive Statistics were carried out to describe the mean, SD, frequencies and percentages. Results were presented through tabulation and graphical representation.

\section{RESULTS}

Results revealed the frequencies and percentages of various motivational factors (Patriotism, Feeling Proud, being Charm of uniform, Bright Career, Job security, Family lineage, Adventurous job, Marriage and financial incentives) to join Army among women. All the participants were unmarried females between 18-30 years. Further details about sample characteristics are explained in table-I.

Table-I shows that most of participants were freshly graduates $746(94.19 \%)$ and not currently doing any job. Among them, 125 (5.78\%) ware from social sciences (Psychology/Mass Communication/IR), 450 (56.81\%) were from engineering, 67 (8.45\%) from basic sciences and 153 (19.31\%) were from other fields.

\begin{tabular}{l|c|c}
\multicolumn{2}{l}{ Table-I: Demographic characteristics of sample (n=792). } \\
\hline Variables & Categories & $\mathbf{n ~ ( \% )}$ \\
\hline \multirow{4}{*}{ Age } & $18-20$ & $5(0.63)$ \\
\cline { 2 - 3 } & $20-25$ & $591(74.62)$ \\
\cline { 2 - 3 } & $26-28$ & $194(24.49)$ \\
\cline { 2 - 3 } & $28-30$ & $2(0.25)$ \\
\hline \multirow{2}{*}{ Family setup } & Joint & $100(12.62)$ \\
\cline { 2 - 3 } & Nuclear & $692(87.37)$ \\
\hline \multirow{2}{*}{ Work Status } & Working & $46(5.80)$ \\
\cline { 2 - 3 } & Non-Working & $746(94.19)$ \\
\hline \multirow{3}{*}{ Field of study } & First Time & $757(95.58)$ \\
\cline { 2 - 3 } & Repeater & $35(4.41)$ \\
\cline { 2 - 3 } & Psychology/Mass & $125(5.78)$ \\
\cline { 2 - 3 } & Communication/IR & $450(56.81)$ \\
\cline { 2 - 3 } & Engineering & $67(8.45)$ \\
\hline
\end{tabular}

Table-II shows the checklist developed by the researcher in first phase of the study after conducting semi-structured interviews of 10 lady officers. In this checklist, 1st motivational factor was "financial reasons" and the factor "marriage" was at the last number in hierarchy.

Table-III shows the frequencies and percentages of each motivational factor rated by the respondents. Among all the motivational factors "Patriotism" has the highest frequency and "financial reasons" was at 
Table-II: Motivational factors.

\begin{tabular}{|c|c|}
\hline \multicolumn{2}{|c|}{ Motivational Factors } \\
\hline \multicolumn{2}{|c|}{ Financial Reasons } \\
\hline \multicolumn{2}{|c|}{ Bright Career } \\
\hline \multicolumn{2}{|c|}{ Job Security } \\
\hline \multicolumn{2}{|c|}{ Family Lineage } \\
\hline \multicolumn{2}{|c|}{ Patriotism } \\
\hline \multicolumn{2}{|c|}{ Charm of Uniform } \\
\hline \multicolumn{2}{|c|}{ Feeling Proud } \\
\hline \multicolumn{2}{|c|}{ Strong Scocial Standing } \\
\hline \multicolumn{2}{|c|}{ Quality of Life } \\
\hline \multicolumn{2}{|c|}{ Adventurous Job } \\
\hline \multicolumn{2}{|c|}{ Marriage } \\
\hline \multicolumn{2}{|c|}{$\begin{array}{l}\text { Table-III: Frequencies and percentages of motivational } \\
\text { factors. }\end{array}$} \\
\hline Motivational Factors & n (\%) \\
\hline Financial reasons & $8(1)$ \\
\hline Bright career & $48(6)$ \\
\hline Job security & $40(5)$ \\
\hline Family Lineage & $40(5)$ \\
\hline Patriotism & $174(22)$ \\
\hline Charm of Uniform & $63(8)$ \\
\hline Feeling Proud & $142(18)$ \\
\hline Strong Scocial Standing & $126(16)$ \\
\hline Quality of Life & $79(10)$ \\
\hline Adventurous job & $40(5)$ \\
\hline Marriage & $32(4)$ \\
\hline
\end{tabular}

the lowest number. Ghraphical representation of results was also shown in figure.

Table-IV shows the differences in motivational factors among participants from various fields of study in which "feeling of proud" was most common motivating factor to join Army among psychologists and mass communication graduates as compared to other factors in general. Whereas, "Quality of Life" was most common motivating factor among natural sciences students.

\section{DISCUSSION}

To find out the most common motivational factor to join army among female graduates, a formalized list

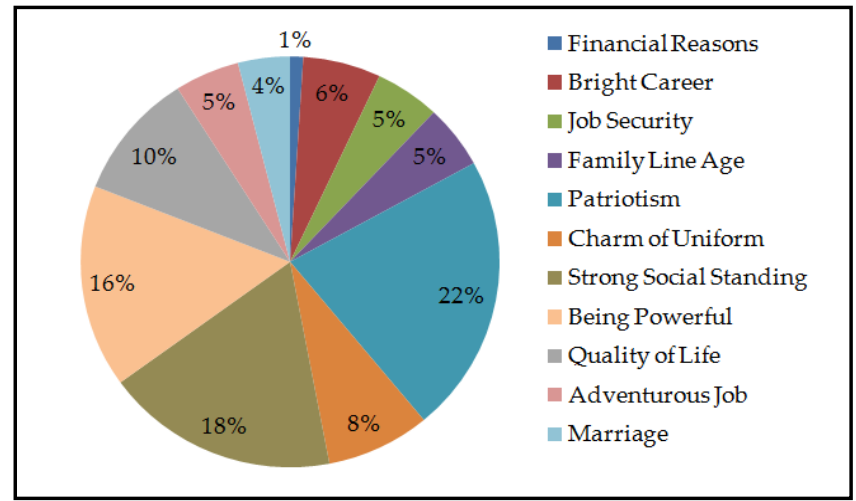

Figure: The percentages for the each motivational factor in ghraphical form to make it more explicit.

of motivational factor has been analyzed by the researcher. For this purpose, a study has been conducted from the sample of 792 females from various universities located in Rawalpindi and Islamabad.

Table-I shows the checklist developed by the researcher in first phase of the study after conducting semi-structured interviews of 10 lady officers. In this checklist, $1^{\text {st }}$ motivational factor was "financial reasons" and the factor "marriage" was at the last number in hierarchy. From the whole sample, maximum individuals $(22 \%)$ rated the factor No. 5 to be placed at $1^{\text {st }}$ in hierarchy i.e, "Patriotism". These findings are in line with previous studies in which it was highlighted that the basic reason behind women to join forces is their feelings of patriotism and to serve for their own country. According to Moynihan and Panday, in current intricate and changing security environment, people's motivation for selecting/choosing the military career is getting less day by day in general. But in such circumstances, women are truly motivated to serve their contraries and getting such women is highly significant and these young women must be considered an asset ${ }^{10}$.

After this variable majority of the sample $(18 \%)$

Table-IV: Differences in motivational factors among participants from various fields of study.

\begin{tabular}{l|c|c|c|c}
\hline Motivational Factors & $\begin{array}{c}\text { Psychologists/mass } \\
\text { com/ IR, } \mathbf{n}(\mathbf{\%})\end{array}$ & $\begin{array}{c}\text { Engineering } \\
\mathbf{n}(\mathbf{\%})\end{array}$ & $\begin{array}{c}\text { Basic Sciences } \\
\mathbf{n}(\mathbf{\%})\end{array}$ & $\begin{array}{c}\text { Others } \\
\mathbf{n}(\mathbf{\%})\end{array}$ \\
\hline Financial reasons & $6(4.8)$ & $5(1.10)$ & $3(4.50)$ & $2(1.30)$ \\
\hline Bright career & $6(5.60)$ & $25(5.60)$ & $6(9)$ & $8(5.20)$ \\
\hline Job security & $8(6 . .4)$ & $17(3.80)$ & $3(3)$ & $7(5.20)$ \\
\hline Family lineage & $7(5.6)$ & $20(4.40)$ & $5(22.4)$ & $36(23.5)$ \\
\hline Patriotism & $26(20.8)$ & $100(22.2)$ & $5(7.50)$ & $15(9.80)$ \\
\hline Charm of uniform & $9(7.20)$ & $35(7.80)$ & $11(16.4)$ & $28(18.3)$ \\
\hline Feeling of proud & $29(23.2)$ & $80(17.80)$ & $5(7.50)$ & $20(13.07)$ \\
\hline Strong Social Standing & $18(14.4)$ & $85(18.90)$ & $10(14.92)$ & $11(7.20)$ \\
\hline Quality of Life & $9(7.2)$ & $44(9.77)$ & $3(4.5)$ & $12(7.80)$ \\
\hline Adventure & $3(2.4)$ & $23(5.10)$ & $4(6)$ & $6(3.90)$ \\
\hline Marriage & $4(3.2)$ & $16(3.60)$ & &
\end{tabular}


reported the variable "Feeling Proud" to be the $2^{\text {nd }}$ Motivational Factor. In Pakistan, Army has most prestigious institute so majority of youth has strong feeling of proud being part of it. Same happened in case of female as well. That's the reason majority of girls placed this option at second.

According to the findings "Strong Social Standing" is considered to be the $3^{\text {rd }}$ Motivational Factor $(16 \%)$ for joining Army. Why this factor is so important for women to join forces is strongly linked with our social-cultural environment of our patriarchal society. As generally women, don't have power and authority in society in general and in any other government or civil sector jobs. Army is only institute where they feel more powerful being in uniform so that is another most significant motivation behind them to join Army. These are the factors which further help army to plan successful strategies not only for the recruitment of women but also regarding their retention and promotions. Lisa et al, carried out detailed analysis in 2015 on the primary concerns in the recruitment and retention process of marginalized and vulnerable populations in military and concluded to potentially sensitive issues of these populations must be carefully considered while their selection ${ }^{11}$.

After that "Quality of Life" is considered to be placed on $4^{\text {th }}$ number in hierarchy $(10 \%)$. Army generally has very well organized and attractive life style which attract women to join it. It's not only in Pakistan, rather all over the world; similar findings are reported in past literature as well 1,9 . Grigorov et al examined the structure of motivation to choose military as a career and ended to the conclusion that it is a complex process of internal and external factors and Army life style has a prominent place in external factors ${ }^{8}$. Similar type of study was conducted in Pakistan by Rauf which showed that young boys are greatly influenced by luxuries of modern life styles and motivated to join Army to get a high status in society ${ }^{1}$. Actual this aspect has dual character. On the one hand, it confirms the effectiveness of financial factors in the motivating process with-in the organization and on the other hand, it showed the value of promotion and position in the hierarchy. Same findings were reported by Bodziany, et $a^{12}$.

Further to this, charm of uniform (8\%) is another very strong factor for female to join Army. Generally, in Pakistan, mostly people inspired by army uniform and when we talk about women and young girls they are mostly inspired by army uniform in general and specifically lady officer's uniform. Lady Officer's uniform is saree in routine which shows elegance and that is the thing mostly young women attracted towards forces. Some of other less common factors to join forces are bright career $(6 \%)$, job security $(5 \%)$, family lineage $(5 \%)$, adventurous job (5\%), Marriage (4\%) and financial reasons $(1 \%)$. When we see the trends in previous researches, it is found that our findings are somewhat similar to them ${ }^{1,7,9}$. As there are certain universal aspects to join Armies but majority of our findings are different that is because of our specific and unique cultural aspects. Actually, there are certain myths and misconceptions about women in our society such as double standards, incidents of unprofessional behavior and indiscipline and cultural stereotypes. These findings help to break these myths and integrating women in army ${ }^{13,14}$. Glick et al, after studying 2, 250 respondents established that positive attitudes help women to explore their potentials in a better way ${ }^{15}$. It was further emphasized by other researchers as well ${ }^{16,17}$. Lilly et al conducted study which showed that the women after training work as good as men in many fields and met the standards ${ }^{18}$. Similar type of findings was also shown by another study as well ${ }^{19}$.

It was further depicted by our findings that there were certain differences among women from various professions on their motivation to join Army. Such as among psychologist and mass communication graduates, feeling of proud is most common motivating factor to join Army as compared to other factors in general. Similarly, among natural sciences students, Quality of Life is also quite high in motivation. That's because of general trend of not getting high packed jobs in these graduates in civil setups as compared to Army. That's why Army's life style is very attractive and motivating to them. Similar type of study with the aim to explore relationship of motivation with the specificity of the profession and the selected socio-professional variable has been done in past by Bodziany et al. Findings of this study suggested that motivating strategies in the examined institutions (uniformed services) depend not only on their structural and functional or legal and organizational culture specificity but also on the individual needs related to the position, corps (officer/non commissioned officer), an individual system of values and social factors such as material and social ${ }^{12}$.

\section{LIMITATION OF STUDY}

This study conducted on small sample of female graduates only from various universities of Islamabad / Rawalpindi, so findings of research are not generaliz- 
able. It is recommended that, in future, more studies with larger sample sizes should be carried out.

It is an exploratory study in which we identified some of reason behind women to join forces. In future, a mix method study is recommended in which along the semi-structure interviews and focused groups, standardized scale should be used to get more in depth knowledge.

\section{RECOMMENDATION}

Present study highlighted the overall importance of motivation in selection process.

It also provided the framework and in-depth understanding of psychological motivation behind women to join army which will help in policy making regarding women induction/recruitment, their placements and promotions. Further to it, understan-ding psychological motivation gives many valuable insights into human nature which will help Pak Army to select best of what nation has to offer. It will help to give valued outcomes such as improved performance, enhanced quality at work / productivity and overall wellbeing of soldiers \& officers

\section{CONCLUSION}

Motivation for opting military career is a complex phenomenon of inter-related factors. It is compounded by societal changes and rapidly altering socio-psychological needs under competitive environment. Therefore, we should consider all these factors together to select highly motivated, skilled/qualified and loyal individuals. Further to this, in current changing social order at an increased pace, women contribution in nation building through various forums is meeting diversity. Armed Forces being an embodiment of national cohesion and integrity needs to maintain the pace with societal changes thus need to enhance its female intake in qualitative and quantitative terms. The factors along with its preferences highlighted above are structured into a framework for perusal at policy level in the Army after a deliberate and incisive analysis by Joint Working group comprising members from all stakeholders. Such efforts would further improve the Lady Officers participation at national and military levels.

\section{CONFLICT OF INTEREST}

This study has no conflict of interest to be declared by any author.

\section{REFERENCES}

1. Rauf M. Psychological motivation behind joining armed forces. J Soc Sci 2010; 2(2): 287-90.
2. Broussard S, Garrison M. The relationship between classroom motivation and academic achievement in elementary-schoolaged children. Fam Consum Sci Res J 2009; 33(1): 106-20.

3. Cigrang JA, Todd S, Carbone EG. Stress management training for military trainees returned to duty after a mental health evaluation: Effect on graduation rates. J Occup Health Psychol 2000; 5(1): 48-55.

4. Brantley H. Patriotism or financial stability -What drives young men and women to join the United States Armed Forces. PhD thesis. Honors College Capstone 2014 [Internet] Available from: https:/ / digitalcommons.wku.edu/cgi/viewcontent.cgi?article=1 $456 \&$ context $=$ stu_hon_theses.

5. Helmus TC, Zimmerman SR, Posard MN, Wheeler JL, Ogletree C. A study of the motivations and experiences of junior enlisted personnel in the U.S. Army. [Internet] Available from: https:// www.rand.org/content/dam/rand/pubs/research_reports/RR 2200/ RR2252/RAND_RR2252.pdf [Accessed on April 21, 2021].

6. Mckay DR. Careers for Women in the Military. Annual Report. DACOWITS. [Internet]. Available from https://www.thebalancecareers.com/women-in-the-military-4177666 [Accessed on March 31, 2021].

7. Mankowski M, Tower L, Brandt C. Why women join the military: enlistment decisions and post deployment experiences of service members and veterans. Soc Work 2015; 60(4): 315-23.

8. Kalkowski K, Fritz S. A survey of gender-related motivation studies. J Agric Educ 2004; 45(2): 19-34.

9. Grigorov $G$, Research on the motivation for choosing the military career. International conference. Knowledge-based Organization. [Internet]. Available from: https://www. researchgate. net/publication/326651563_Research_on_the_Motivation_for_ Choosing_the_Military_Career. [Accessed on March 31, 2021].

10. Moynihan DP, Pandey SK. The role of organizations in fostering public service motivation. Public Adm Rev 2007; 67(1): 40-53.

11. Lisa A, Braun NC, Holly P, Kennedy AN, Lois S. Research on U.S. Military Women: Recruitment and Retention Challenges and Strategies. Mil Med 2015; 180(12): 1247-52.

12. Bodziany M, Ścibiorek Z, Ślusarczyk S. Motivating in theory and practice of command-case study of the Polish armed forces, the police and the fire service. Int J Organ Anal 2020; 29(2): 474-92.

13. Robert BN. U.S. Senate Armed Services Committee, Testimony of U.S. Marine Corps Commandant. [Internet]. Available from: https:// www.appropriations.senate.gov/imo/media/doc/ 05.01.19Neller\%20Testimony.pdf. [Accessed on March 31, 2021].

14. Lynette A. Gender Integration Study-Fort Leavenworth, KS: U.S. Army Training and Doctrine Command Analysis Center. [Internet]. Available from: https://dod.defense.gov/Portals/1/ Documents/wisr-studies/Army\%20 [Accessed on Mar 31, 2021].

15. Glick $P$. The ambivalent sexism inventory: differen-tiating hostile and benevolent sexism. J Pers Soc Psychol 1996; 70(3): 491-12.

16. Reuben E, Sapienza P. How stereotypes impair women's careers in science. Proc Nat Acad Sci USA 2014; 111(12): 4403-4408.

17. Tan M. First Official Integrated Ranger School Underway, Army Won't Talk About the Women. Army Times. [Internet] Available from: https://www.armytimes.com/news/your-army/2015/ 11/04/ first-official-integrated-ranger-school-underway-armywon-t-talk-about-the-women.[Accessed on March 31, 2021].

18. Lilly K, Tan M. Army's New Fitness Tests: New Details Emerge from Leadership," Army Times 2019 [Internet] Available from: https://www.armytimes.com/news/yourarmy/2016/02/19/army-s-new-fitness-tests-new-detailsemerge-from-leadership.[Accessed on March 31, 2021].

19. Elizabeth MT. Women, Regardless: Understanding Gender Bias in U.S. Military Integration. NDU Press 2018; 88(1): 1-8. 